\title{
Bilateral primary testicular lymphoma
}

\author{
Edith Vassallo, ${ }^{1}$ Richard Pullicino, ${ }^{1}$ Reuben Grech, ${ }^{1}$ Adrian Mizzi ${ }^{2}$
}

${ }^{1}$ Department of Medical Imaging, Mater Dei Hospital, Msida, Malta

${ }^{2}$ Department of Radiology, Mater Dei Hospital, Msida, Malta

\section{Correspondence to} Dr Edith Vassallo, edithvassallo@gmail.com

Accepted 9 March 2014

\section{DESCRIPTION}

A 56-year-old man presented to his general practitioner with a painless, rapidly growing left testicular mass over a period of 3 months. The patient was a known case of type II diabetes mellitus and hypertension with no relevant surgical history. He did not report any dysuria, fever or weight loss. On examination, there was bilateral diffuse, non-tender testicular enlargement without regional lymphadenopathy.

Sonographic assessment revealed an enlarged left hypoechoic testicle measuring approximately $5 \mathrm{~cm}$ in width and $8 \mathrm{~cm}$ in length. It demonstrated a diffusely heterogenous infiltrative pattern (figure 1A) and increased internal Doppler flow (figure 1B). The right testicle measured $5 \mathrm{~cm} \times 6 \mathrm{~cm}$ with otherwise similar sonographic findings (figure $2 \mathrm{~A}, \mathrm{~B})$. These features are non-specific and the differential diagnosis includes orchitis, primary testicular tumours, leukaemia, testicular torsion and sarcoidosis. Histology is thus warranted to confirm the diagnosis.

The patient underwent a left inguinal orchidectomy and was diagnosed with diffuse primary large B-cell non-Hodgkin's lymphoma. A right orchidectomy was performed 1 month later. Bone marrow aspirate and trephine biopsy were normal and he was started on a dedicated chemotherapeutic regimen.

Primary testicular non-Hodgkin's lymphoma accounts for $1-2 \%$ of all non-Hodgkin's lymphomas and $5 \%$ of testicular cancers. ${ }^{1}$ It affects older men (mean age 67 years) and the most common histological subtype is diffuse large B-cell lymphoma. Presentation is usually with a unilateral testicular mass and up to $90 \%$ have stage I/II disease at diagnosis with bilateral testicular involvement occurring in $35 \%$ of cases. $^{2}$ Relapse and extranodal infiltration is common.

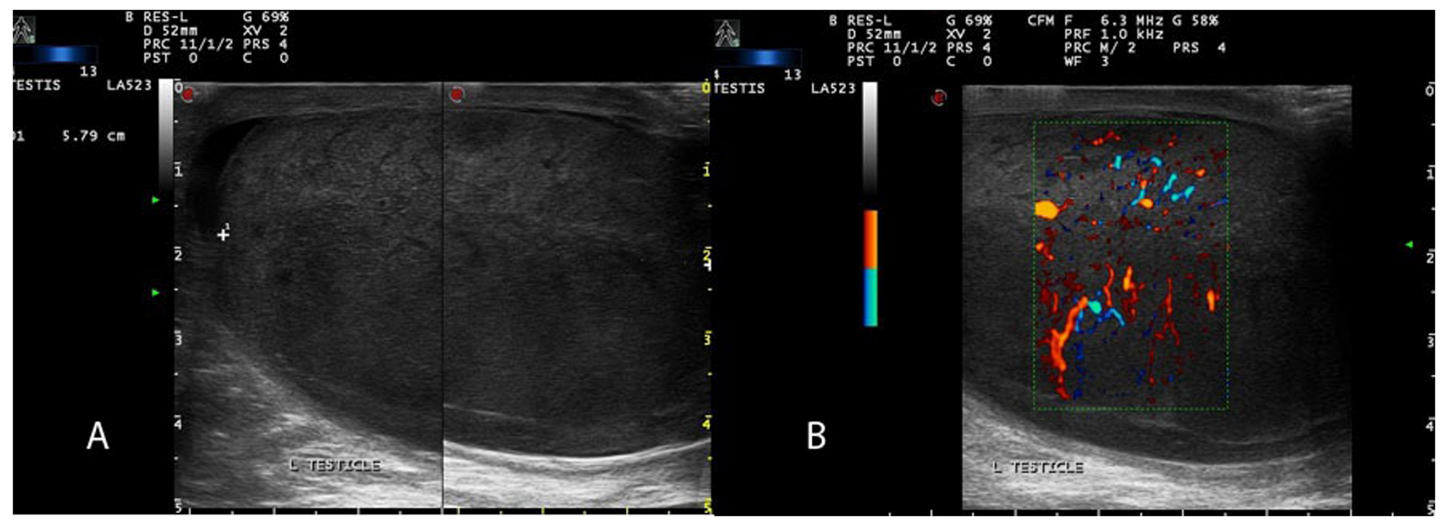

Figure 1 (A) B mode ultrasound image demonstrates an enlarged left testicle with a diffusely heterogenous echotexture suggestive of an infiltrative process. (B) Colour Doppler interrogation reveals marked generalised hyperaemia.

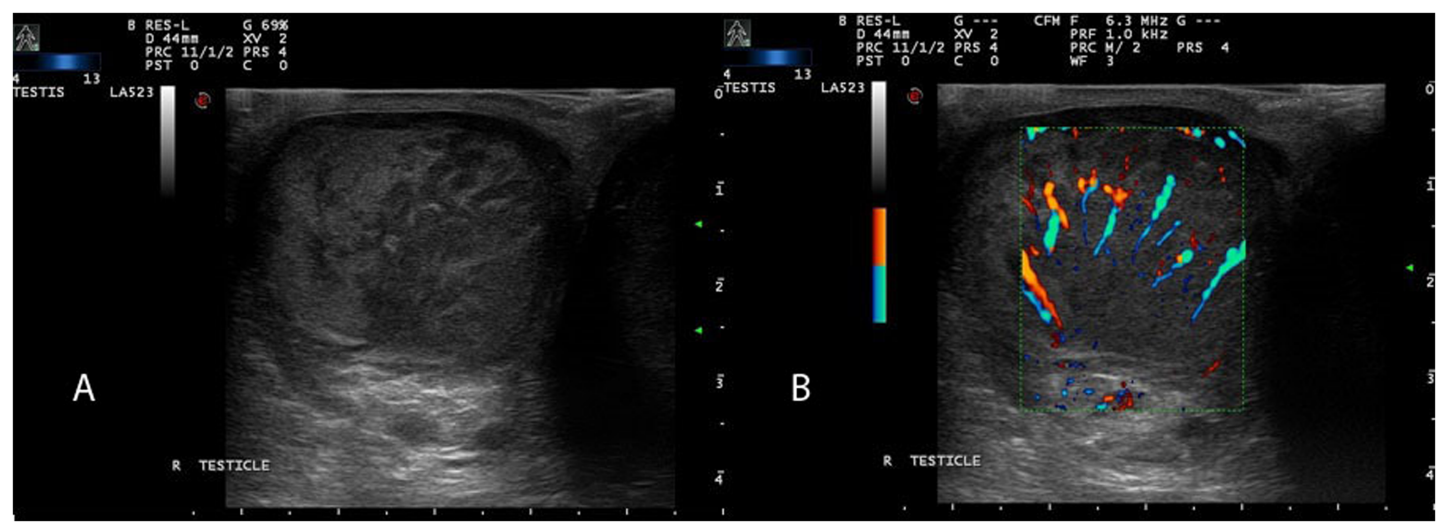

Figure 2 (A) Ultrasound scan of the right testicle demonstrates findings similar to those on the left with diffuse swelling and an abnormal infiltrative intraparenchymal pattern. (B) There is increased internal flow at Doppler interrogation. 


\section{Learning points}

- Primary testicular lymphoma is rare accounting for $1 \%$ of non-Hodgkin's lymphomas and usually occurs in older men.

- Treatment for early stage disease comprises of orchidectomy followed by chemotherapy and prophylactic scrotal radiotherapy with/without iliac, para-aortic lymph node radiotherapy.

- Ultrasound usually reveals a diffuse infiltrative heterogenous process with increased vascularity on Doppler interrogation.

- Clinical data and inputs from a multidisciplinary team are important for effective patient management.
Acknowledgements The authors would like to thank the urologists and haematologists who provided very important feedback with regard to the clinical aspect of this patient's condition. They contributed significantly to the patient being promptly diagnosed and receiving a high standard of care.

Contributors EV was involved in literature research. EV, RP and RG were involved in manuscript preparation. RG and AM were involved in manuscript editing.

Competing interests None.

Patient consent Obtained.

Provenance and peer review Not commissioned; externally peer reviewed.

\section{REFERENCES}

1 Zouhair A, Mirimanoff RO, Ozsahin M. Primary testicular lymphoma. Management of Rare Adult Tumours, 2010:255-9.

2 Ahmad SS, Idris SF, Follows GA, et al. Primary testicular lymphoma. Clin Oncol 2012;24:358-65.

Copyright 2014 BMJ Publishing Group. All rights reserved. For permission to reuse any of this content visit http://group.bmj.com/group/rights-licensing/permissions.

BMJ Case Report Fellows may re-use this article for personal use and teaching without any further permission.

Become a Fellow of BMJ Case Reports today and you can:

- Submit as many cases as you like

- Enjoy fast sympathetic peer review and rapid publication of accepted articles

- Access all the published articles

- Re-use any of the published material for personal use and teaching without further permission

For information on Institutional Fellowships contact consortiasales@bmjgroup.com

Visit casereports.bmj.com for more articles like this and to become a Fellow 